\title{
The Viol da Gamba as a Sexual Metaphor in Elizabethan Music and Literature
}

\author{
GUSTAV UNGERER
}

The best-known reference to the viol da gamba in Elizabethan literature is likely to be Sir Toby Belch's ironical eulogy of Sir Andrew Aguecheek as an accomplished gambist. Sir Toby claims that his boon companion " word without book, and hath all the good gifts of nature" (I.3.23-5). ${ }^{1}$ His irony is so clear that modern editors of Shakespeare's romantic comedy Twelfth Night do not deem it necessary to draw attention to the sexual innuendo of the musical instrument. The purpose of this article is to trace part of the European history of the sexual joke. It will be shown that, under the impact of some English satirists, the expression "playing on the viol da gamba" took on a disparaging meaning. In Shakespeare's time it was a stock phrase with which to heap derision on amateur musicians who, when playing the viol, assumed what was ironically taken to be an indecent posture.

The joke is of very old standing. It probably took its rise in Italy and from there spread through Renaissance Europe. Originally the playing position of the viol da gamba was not standardized. The instrument was held either between the knees or placed on a chair, sometimes on a stool, or put across the knees. ${ }^{2}$ By the end of the sixteenth century, however, the Italian method of holding the instrument between the knees had been adopted throughout Europe for whole consorts, though, as Thurston Dart points out, when the viol was used in some broken consorts of soft instruments, "the older position across the knees was retained, since it gave a far softer tone." Thomas Morley's Consort Lessons (1599) provides an exception to the standard practice. ${ }^{3}$

The playing position favoured by the Italians was a matter of technique as well as a question of aesthetics. This is borne out by the music treatises dealing with string instruments in general, and viols in particular. Thus Silvestro Ganassi's Regola Rubertina (1542/3), the only comprehensive treatise on string instruments in the sixteenth century, gives precise instructions on the method of holding the viol da gamba; and in the preface to 
the Regola the author expresses the traditional view that playing an instrument is an art that appeals to both the ear and the eye. The movements of the player's body must therefore be harmonious and the position of the hand graceful. ${ }^{4}$

Among the English music teachers the first to lay particular emphasis on the aesthetic aspect of playing the viol da gamba is Christopher Simpson. His predecessors and contemporaries such as Thomas Robinson in The Schoole of Musicke (1603), John Playford in A Brief Introduction to the Skill of Music (1658), and Thomas Mace in his Musick's Monument (1676) are silent on this point. ${ }^{5}$ They content themselves with giving practical instructions. Not so Christopher Simpson who in his perceptive study of The Division-Viol, or, The Art of Playing Ex tempore upon a Ground. Divided into Three Parts (London, 1667) insists that the posture must be correct and decent. ${ }^{6}$

Of the several paragraphs Simpson devoted to explaining the technical minutiae of playing the viol da gamba or bass viol, the fourth and the twelfth are of particular interest for our present argument. "Being conveniently seated," Simpson lectures to the practitioner, "place your Viol decently betwixt your knees; so, that the lower end of it may rest upon the calves of your legs. Set the Soles of your feet flat on the floor, your Toes turn'd a little outward. Let the top of the Viol be erected towards your left shoulder; so, as it may rest in that posture, though you touch it not with your hand" (p. 2). Moreover, under the heading "The Motion of the Right Arm and Wrist" (Paragraph 12, p. 7), he adds the following warning so as to prevent the player from cutting a poor figure and becoming the laughingstock of the onlookers: "I told you before that you must stretch out your Arm streight, in which posture (playing long Notes) you will necessarily move your shoulder Joint; but if you stir that Joint in quick Notes, it will cause the whole body to shake; which (by all means) must be avoyded; as also any other indecent Gesture." He therefore does "much approve the streightness of the Arm, especially in Beginners, because it means to keep the Body upright, which is a commendable posture" (p. 8). These instructions are illustrated by a print showing a gambist holding his instrument in a professionally correct position. ${ }^{7}$

Bawdy jokes about the standard posture seem to have been fashionable among the leisured classes about the time Ganassi issued his Regola Rubertina. The first instance known to me is offered by Giovan Francesco Straparola's Le piacevoli notti, a collection of licentious and satirical tales, which scored an overwhelming success among Italian readers of the sixteenth century. ${ }^{8}$ The tales are told by a bevy of ten beautiful and virtuous ladies-in-waiting upon Lucrezia, the daughter of Ottaviano Mario Sforza, bishop of Lodi. Each tale is followed by a riddle that admits of two solutions, one of them being indecent. The riddle pertinent to our dis- 
cussion is dished up by the blue-eyed Lodovica at the end of the second tale of the twelfth night. She both leads and misleads the audience she addresses:

Cortesi donne mie, vommi a trovare

L'amico che mi da tanto diletto.

Ed ivi giunta, tosto me'l fo dare,

E tra una coscia e l'altra me lo metto

Quella novella poi, che rallegrare

Tutte vi face, piglio; e inanzi e indietro

Menandola, ne manda un dolce fuore,

Che languire vi fan spesso d'amore. ${ }^{9}$

As some of the ladies blame Lodovica for having told a ribald enigma, she administers, in defence of her honour, a reproof to those who have harboured lewd thoughts. "Those who are full within of lewdness and malignity," she comments, "can only put forth what is unclean and evil, and those of you who are in such case have judged my words to mean something entirely foreign to my own conception of them; for this enigma of mine is simply intended to describe the viol da gamba, which instrument a lady, when she desires to play upon the same and give delight to her friends around, places between her knees, ${ }^{10}$ and then, having taken in her right hand the bow, she moves this to and fro in order that she may draw forth from her instrument those sweet sounds which in sooth often make us faint and sick with love." 11 Lodovica's ingenious interpretation of the "sottile enimma" appeases the sophisticated company, which is honoured by the presence of such distinguished guests as Pietro Bembo, Bernardo Cappello, and bishop Gregorio Casali, ambassador of Henry VIII to the Vatican.

Straparola's spicy tales won the favour of an international public. They were translated into Spanish by Francisco Truchado (Bilbao, 1580; Baeza, 1581) and into French by Jean Louveau (1560) and Pierre de Larivey (1572). Larivey, canon of Saint-Etienne and author of some prose comedies, added to the ribaldry of the Italian enigmas by expanding them into French sonnets. ${ }^{12}$ The canon's erotic elaboration reads: ${ }^{13}$

Je ne le veux celer, quand je me trouve à point,

Je vas ${ }^{14}$ veoir mon amy, je le pren, ${ }^{15}$ je l'embrasse,

Et si souvent son nerf ${ }^{16}$ entre mes doigts je passe

Que je le fais roidir, ne le voulust il point.

Après, le voyant prest, gaillard et bien en point,

Mes deux cuisses s'ouvrant d'un assez large espace,

Je le mects entre deux, et si bien je le place,

Qu'on ne nous diroit qu'un, tant de près il me joint.

Adonc, d'un maniment fretillard et adextre,

Remuant haut et bas, ore à gauche, ore à dextre,

Entre mille douleurs j'accomply mon désir; 
Et si par fois son nerf devient lasche et s'abaisse, Avecques les deux doigts si bien je le redresse, Que plus qu'auparavant j'en tire du plaisir.

Though the contemporary music theorists recommend holding the viol between the "knees," Straparola and Larivey flout their rules. They speak of placing the instrument between the "thighs" of the player. Moreover, the two adapt the musical metaphor to the conventional anacreontic conceit. In imitation of love poetry in which the lover burns to assume such fancy shapes as a flea, a bee, a lap-dog, a jewel, or even a glove, etc., Lodovica's riddle toys with the erotic equation between a lover (or beloved) and the stringed instrument. In Larivey's expanded version of the riddle the sweet pangs of sexual embrace suggest an ecstatic finale. ${ }^{17}$

There were a number of reasons that must have induced Straparola to relate a lover to a viol da gamba. His comparison drew on the commonplace view that the creation was an act of music and the universe an instrument perfectly tuned. And as man was conceived as a microcosmic image reflecting the celestial world, he came to be compared to all kinds of musical instruments, ranging from wind to string instruments. In as much as man was bound by cords and tendons, fibres and nerves that respond to stimulus, he or she or the parts of his or her body, as G.L. Finney observes, used to be likened to a lute or viol. ${ }^{18}$ Shakespeare, for instance, has put this view to dramatic use in Pericles. When Pericles discovers the incestuous relation between King Antiochus and his daughter, his reaction is definite. He tells the princess (I.1.82-7):

You are a fair viol, and your sense the strings,

Who, fingered to make man his lawful music,

Would draw heaven down and all the gods to hearken;

But, being played upon before your time,

Hell only danceth at so harsh a chime.

Good sooth, I care not for you.

Did Straparola prepare the ground for the bawdy viol imagery in England? He may well have done so if we bear in mind that Lodovica's erotic riddle was bound to be known to Gabriel Harvey and Robert Armin, Shakespeare's colleague. Harvey owned a copy of the two parts of the Piacevoli notti, ${ }^{19}$ and Armin, under the influence of a kindred spirit, was inspired to write Phantasma, the Italian Tailor and His Boy (1609), a verse rendering made from the fifth tale of the eighth night. ${ }^{20}$ Moreover, the presence of bishop Gregorio Casali, ambassador of Henry VIII, among the distinguished guests, who, as Straparola pretended, were entertained by the narrators, might have won a reputation for his tales in England.

However, as bawdy jokes about musical instruments were a common- 
place in Renaissance Europe, Straparola can hardly claim to have initiated in England the joke about the viol as a sexual metaphor. Besides there was a strong demand for and heavy traffic in riddles as can be gathered, for instance, from Humphrey Gifford. He appended sixteen riddles of Italian origin to his Poesie of Gillowflowers (1580). The tenth riddle concerns a lute: ${ }^{21}$

A certain dead creature in mine armes I take,

With her back to my bosome, great glee doth shee make.

As thus I doe hold her, she greatly doth cheere mee,

And wel are they pleased, that see me and heare mee.

Whilst erst it remayned in forest and field,

It silent remayning, no speech forth did yeeld.

But since she of life, by death was deprived,

With language shee speaketh, mens sprites are revived.

With the rising popularity of the bass viol as a solo instrument in England, the practice of playing came to be considered as an accomplishment of the educated gentleman and gentlewoman. There was, however, a tendency to look down on the bass viol as an indecent instrument for woman. Though Sebastian Wengrave states, in Dekker's The Roaring Girl or Moll CutPurse (1611), that "there be a thousand close dames that wil cal the viall an vnmannerly instrument for a woman," 22 there must have been as many who would have objected. The sister of Philip Gawdy, the court gossip, would certainly have been among the objectors. ${ }^{23}$

The lute had been the favourite instrument with which to accompany songs, but towards the close of the sixteenth century it was being ousted by the bass viol. Many books of songs and airs, such as John Dowland's First Booke (1597), were specially designed so that all the songs could "be song to the Lute, Orpherion or Viol de Gambo." Philip Gawdy's sister obviously took to playing the viol as an accompanying instrument. So did the Lady who played upon "a fayre Violl da gamba ... and sung thereto with a voyce so sweet and heauenlie, that Primaleon" would often "urge her to play some lessons twise or thrise ouer, and to sing againe diuers of her ditties." 24

The viol da gamba also came into its own at the Inns of Court. Edward Waterhouse explicitly stated in Fortescutus illustratus (1663) that, as "singing and playing on instruments" were held a "very great addition to a Gentleman," it became an "Inns of Court-man" to be a gambist. ${ }^{25}$ The students did apply themselves, in their extra-legal studies, to acquiring a mastery of the viol. Thus John Ramsey, who, at the age of twenty-six, was admitted to the Middle Temple in 1606, kept a commonplace book in which he entered his favourite "Songes \& Dittyes to the Lute and Viol de gambo." Among them figure six songs from Dowland's first and second 
book. ${ }^{26}$ In the early 1620 s another Templar, William Freke, paid Robert Tailor, a member of the King's Music, 6 s. a month for viol lessons. ${ }^{27}$

The fashion of playing the bass viol caught on so well that it aroused the barbed reaction of three young satirists. They were members of the Inns of Court who addressed their outspoken and licentious satires to their fellow residents. Their works, published in the same year (1598), some even as a joint venture, caused such a stir that they were ordered to be burnt by the archbishop of Canterbury in 1599. Ambitious and quick-witted, as they were, these keen observers of human foibles spared neither foe nor friend. They were John Davies (1569-1626), who entered the Middle Temple in 1588; Everard Guilpin (1572), who was admitted to Gray's Inn in 1591 and married Marston's cousin Sarah Guarsi; and John Marston, who took up quarters at the Middle Temple before 1595.

Davies was the first to ridicule the fashion in a pungent poem written in 1594 or 1595 and published anonymously in the first and second edition of his notorious Epigrammes (Middleborough, 1598). In accordance with epigrammatic style, it is addressed to a loose woman: ${ }^{28}$

Faith (wench) I cannot court thy sprightly eyes,

With the base Viall placed between my Thighes;

I cannot lispe, nor to some Fiddle sing,

Nor run uppon a high strecht Minikin.

The real-life epigram is in agreement with Straparola's riddle in so far as Davies, too, has shifted the playing position of the viol from the knees to the thighs. The sexual wordplay is in line with the immoral spirit of the traditional law-sports and revels that were observed annually at the Inns of Court. ${ }^{29}$ Thus Davies invites his sophisticated readers to spot a joke on thighs as a symbol of sexual potency.$^{30} \mathrm{He}$ also seems to expect them to be so sensitive to wordplay as to sense the eye/pudend pun in "sprightly eyes"; 31 and finally he is toying with musical terminology in "strecht Minikin," implying both a "taut treble string of the lute or viol" and a "prostrate wench." 32

The topicality of the sexual metaphor is also attested by John Marston's first satire, which was published in Certaine Satyres (1598) with a view to entertaining the choice spirits of the Templars. The butt of Marston's mordant pen is one Briscus, presumably a fellow student, who is derided in terms almost identical to John Davies': ${ }^{33}$

Come Briscus, by the soule of Complement,

I'le not endure that with thine instrument

(Thy Gambo violl plac'd betwixt thy thighes,

Wherein the best part of thy courtship lyes)

Thou entertaine the time, thy Mistres by. 
Marston, obsessed with sex, finds fault with Briscus for wheedling his beloved with an indecently placed musical instrument instead of winning her by the qualities of eloquent conversation and refined thought. Another relevant instance occurs in the Induction to his play The Malcontent (acted about 1602). William Sly, one of the principal actors of the King's Men, asks Sinklo, possibly one of the hired actors, to sit between his legs. Sinklo refuses, for "the audience then will take me for a viol-de-gamba, and think that you play upon me." ${ }^{34}$ Obviously this is a dig at homosexuality.

Guilpin delights in exploring the viol conceit in Skialetheia (1598), a collection of Epigrams and Satyres which, as its modern editor observes, is the literary product of the world of the Inns of Court. In the forty-sixth epigram Guilpin levels the shaft of his biting satire at a foppish woman: ${ }^{35}$

The world finds fault with Gellia, for she loues

A skip-iack fidler, I hold her excus'd,

For louing him, sith she her selfe so proues:

What, she a fidler? tut she is abus'd?

No in good faith; what fidle hath she vs'd?

The Viole Digambo is her best content,

For twixt her legs she holds her instrument.

The success of the bawdy couplet resounded as far as Cambridge where in 1588 Guilpin had matriculated as a student. The couplet was appropriated by the students of St John's College and inserted in the Second Return from Parnassus for the performance of $1601 / 2$. In the play Sir Raderick complains to the Recorder about the students playing knavish tricks on him. One among those "pestilent fellowes," who "speake nothing but bodkins, and pisse vinegar," he chafes, was so impudent as to make "a couple of knauish verses on" smoking tobacco in his house and another was so saucy as to make a couplet on his "Daughter that learnes to play on the violl de gambo":

Her violl de gambo is her best content

For twixt her legges she holds her instrument. ${ }^{36}$

The physicality the three young satirists infused into the viol image contrasts with Ben Jonson's inoffensiveness in Every Man Out Of His Humour (1599). Jonson dedicated the play to the gentlemen of the Inns of Court, with some of whom he was on close terms while writing the comedy, and, as it seems, he pandered to their craze for sexual jokes. Thus Fastidius Brisk when courting Saviolina, a lady with a light wit, takes down her viol from the wall and declares that, though it is newly strung, it is "miserably out of tune, by this hand." Saviolina then tunes the viol, thus proving the foolish gallant to be a poor player unable to arouse the instrument with the 
touch of his fingers. She fascinates her smoking suitor so much that he offers to tell "a good iest now....: I haue wisht my selfe to be that instrument (I thinke) a thousand times, and not so few, by heauen." 37

What the asinine Brisk styles a good jest, simply turns out to be a variation of the anacreontic conceit as already implied in Straparola's riddle. ${ }^{38}$ The only novelty about Brisk's stale jest lies in his choice of the musical instrument, but even the novelty may be questioned considering the current use of the anacreontic conceit in contemporary poetry. ${ }^{39}$ The poem "The Lady and her Viol," which is attributed to John Donne, may serve by way of illustration. In this poem, the lover, jealous of the viol, complains: ${ }^{40}$

\footnotetext{
Why dost thou, dear, affect thy viol so,

And let thy love forlorn with anguish go?

Thou'lt kindly set him on thy lap, embrace

And almost kiss, while I must void the place.

Thou'lt string him truly, tune him sweetly, when

Thou'lt wrest me out of tune and crack me then.

Thou'lt stop his frets, but set no date to mine.

Thou'lt give whate'er he wants, but let me pine.

Thou know'st him hollow hearted, yet wilt hear

Him throughout with an attentive ear;

And sing him much a pleasing lullaby,

Would charm hell's churlish porter's watchful eye,

Keeping true time with him as true may be,

But find no time to keep thee true to me.

Dear, as the instrument would I were thine,

That thou mightst play on me or thou wert mine.
}

The masculine gender of the viol is due to the fact that the spurned lover views the viol as a rival.

The revels celebrated at the Middle Temple during the Christmas festivities of $1597 / 8$ clinch the argument that the viol conceit with its inherent bawdry had become a stock joke of the law students by 1597 . The Prince d'Amour, the ruler over the disorders, who was impersonated by Richard Martin, "a very handsome man, a gracefull speaker, facetious, and well-beloved," 41 disposed of a staff of clerks, officers, and Knights of the Order of the Quiver. The twenty-seventh Article of the Order decreed that "No Knight being out of matter shall revenge himself upon a base Viol." "42 Written in the irreverent spirit of the mock solemnities, the Article is crammed with sexual puns. To modern ears the innuendoes fall flat, but to the revelling law-students and their guests, who were attuned to the frivolous vein of festive licence, the wording must have meant that no Knight suffering from a shortage of seminal fluid should take to a bass viol as a substitute for a woman. Whoever among the Templars wrote the text of the Articles, be it Benjamin Rudyerd, Richard Martin, John Davies or 
John Hoskyns, he drew on medical authority for the twenty-seventh Article. The term "matter" in Renaissance physiology was applied to the fluids of the body $(O E D)$ and, as can be gathered from Vicary's treatise, it signified spermal fluid. ${ }^{43}$ The term was common property, and more than one passage in Shakespeare's and Jonson's plays are now acknowledged to be laced with this medical term. ${ }^{44}$

A further innuendo lies behind the name of the newly founded Order of the Quiver, for the principal duty of the merry-making Knights was to vow subservience to their ladies, paying devoted attention to their seats of nature or quivers. The bawdy meaning of quiver is borne out by one of Greene's "conny-catching" pamphlets (1592) in which a whore's quiver is said "to be open to every arrow." 45 The vulva image, inspired by the viol conceit, was no doubt backed by the viol/vial/phial pun. ${ }^{46}$ Thomas Middleton, a member of Gray's Inn, affected this pun in his dramatic works. Primero, the bawd-gallant in Your Five Gallants (c. 1605), and his courtesans pretend to run a music school, whose scholars meet "sometimes in every corner of the house, with their viols between their legs, and play the sweetest strokes." ${ }^{47}$ Onesiphorus Hoard, in A Trick To Catch the Old One (1605), informs his friend Limber that his nubile niece "now remains in London ... to learn fashions, practise music; the voice between her lips, and the viol between her legs; she'll be fit for a consort very speedily." 48

It stands to reason that Sir Toby's ironical commendation of Sir Andrew Aguecheek as a gambist must be seen in the light of the topical viol conceit. It makes sense only if seen as a further instance of the conceit that Davies, Marston, Guilpin, and Jonson had popularized by 1599 and that Middleton and others were to follow in their works.

Given the fact that the first recorded performance of Twelfth Night took place at the Middle Temple on Candlemas Night (2 February 1602), it is justifiable to suspect that Sir Toby in passing off his hanger-on as a gambist is just playing up to the Templars, the law-students and their Readers, entertaining them with a standing joke of their own. The audience watching this grand finale of the Christmas festivities is likely to have associated the topical term with the satirical lines of either Davies, Marston, or Guilpin. Thus the meaning of Sir Toby's commendation of Sir Andrew as a gambist can be summed up in the couplet:

The viol de gambo is his best content,

For twixt his legs he holds his instrument.

Sir Toby, then, affects the viol da gamba conceit in order to poke fun at Sir Andrew's sexual inadequacy. ${ }^{49}$ The sexualized musical metaphor conjures up the picture of Sir Andrew fondling and fingering, instead of a 


\title{
woman, a stringed instrument indecently placed in a straddling posture between his spindly thighs. ${ }^{50}$
}

\author{
University of Berne, Switzerland
}

\section{Notes}

1 Quoted from Twelfth Night in the New Penguin Shakespeare, ed. M.M. Mahood (Harmondsworth, 1968 ; rpt. 1971). Subsequent quotations from Shakespeare's plays are made from the same edition.

2 Jambe de Fer, Epitome musical (1556), ed. François Lesure in Annales musicologiques, 6 (1958-63), 341-87.

3 See Dart's chap. on "The Viols" in Musical Instruments Through the Ages, ed. Anthony Baines, Pelican Book (Harmondsworth, 1961), 187.

4 Wolfgang Eggers, Die 'Regola Rubertina' des Silvestro Ganassi, Venedig 1542/3. Eine Gambenschule des 16. Jahrhunderts. I: Vollständige Uebersetzung. II: Kommentar (Kassel, 1974), chap. i.

5 Robinson's treatise has been reprinted in The English Experience, No. 589 (Amsterdam, 1973); Playford's relevant instructions can be read in Nathalie Dolmetsch, The Viola da Gamba, Its Origin and History, Its Technique and Musical Resources (New York, 1962; rpt. 1975), 33; Mace recommends a "Natural-Posture" in his Musick's Monument; or, A Remembrancer of the Best Practical Musick, both Divine, and Civil, ed. Jean Jacquot and Andre Souris in the collection Le Choeur des Muses (Paris, 1966), i, 247-8.

6 The first edition dates from 1659; the 1667 edition is available in a facs. rpt. (London, 1955).

7 The print is reproduced by Dolmetsch and in The New Grove Dictionary of Music and Musicians, ed. Stanley Sadie, vol. 19 (London, 1980), 798.

8 The first part ran into three editions between 1550 and 1555; the second part ran into four editions between 1553 and 1557; and the two parts printed together ran into at least twenty editions between 1556 and 1601. All the 16th-century editions come from Venetian printing offices, the first nine from Comin da Trino's. Twice the work was put on the Index librorum prohibitorum. See Giuseppe Rua's edition (Bologna, 1899), i, pp.xix-xx.

9 Quoted from the text edited by Rua (Bologna, 1908), ii, 233. The Victorian translator offers the following rendering: "Gentle dames, I go to find/ What aye to me is blithe and kind,/ And having found it, next I ween/ I set it straight my knees [sic] between;/ And when I rouse the life that dwells/ Within, and soon its virtue tells./ As to and fro my hand I sway,/ Beneath my touch sweet odours play -/ Delights which might a savage move,/ And make you faint through too much love." Quoted from The Nights of Straparola. Now first translated into English by W.G. Waters (London, 1894), ii, 245.

10 Straparola's text has "thigh": "mette tra l'una coscia e l'altra" (ii, 234); so has Larivey's French translation: "met entre ses cuisses" (ii, 326).

11 Quoted from the English translation by Waters, 246.

12 Part i of Straparola's work was translated by Jean Louveau and published in 1560. Part ii was translated by Larivey and published together with Louveau's version of part i in 1572 . Larivey corrected Louveau's translation and cast the riddles into sonnets. There were, to believe Michaud's Biographie universelle, vol. 40 (Paris, 1854), eleven editions between 1572 and 1615.

13 Quoted from Les Facetieuses Nuits de Straparole traduites par Jean Louveau et Pierre de Larivey, ed. P. Jannet, 2 vol. (Paris, 1857), ii, 325.

14 Current 16th-century form of "vais".

15 Current 16 th-century form of "prends".

16 The meaning is both "string" and "membrum virile". See Pierre Guiraud, Dictionnaire historique, stylistique, rhétorique, étymologique de la litterrature érotique (Paris, 1978), 31. 
17 Michele de Filippis remarks in The Literary Riddle in Italy to the End of the 16th Century, Univ. of California Publications in Modern Philology, vol. 34 (1948), that one of the most prominent characteristics of Italian riddles is their obscenity (p. 14).

18 Gretchen L. Finney, “A World of Instruments”, ELH, 20 (1953), 87-120.

19 He owned a copy of the Venice edition by Lorenzini da Turino of 1560 . It is now preserved at the Folger Shakespeare Library. See Virginia F. Stern, Gabriel Harvey, His Life, Marginalia and Library (Oxford, 1979), 236.

20 Charles S. Felver, Robert Armin, Shakespeare's Fool, A Biographical Essay, Kent State University Bulletin (Ohio), Research Series V, Jan. 1961, 73-7.

21 Quoted from A. Brandl, "Noch eine Rätselsammlung der Shakespeare-Zeit", Jahrbuch der deutschen Shakespeare-Gesellschaft, 45 (1909), 139-145. The equation between woman and lute is also made evident by the use of the feminine gender. This was common practice. Anthony Bret, a Langford yeoman in Essex, states in his will (1588) that he has laid out money for a $\mathrm{Mr}$ Jerome "For taking of $(f)$ the belly of a lute and for gluing her, and for new pins and strings for the said lute, 4s.". See F.G. Emmison, Elizabethan Life: Home, Work, Land (Chelmsford, 1976), 23-4.

22 The Dramatic Works of Thomas Dekker, ed. Fredson Bowers, iii (Cambridge, 1966), p. 67, IV.1.93-4.

23 Philp Gawdy, residing in London, sent his sister "two songs for the viol" in 1602. See Walter L. Woodfill, Musicians in English Society from Elizabeth to Charles I (Princeton, 1953; rpt. New York, 1969), 224.

24 Francisco de Moraes, The third and last part of Palmerin of England, translated by Anthony Munday (London, 1602), fol. 119. Quoted from Gerald G. Hayes, Musical Instruments and Their Music 1500-1700 (OUP, 1930), ii, 110.

25 Robert William Wienpahl, Music at the Inns of Court during the Reigns of Elizabeth, James, and Charles, publ. by University Microfilms (Ann Arbor, 1979), 170-1.

26 Bodleian Library, MS Douce 280, fol. 204-6.

27 Wienpahl, 178.

28 The Poems of Sir John Davies, ed. Robert Krueger and Ruby Nemser (Oxford, 1975), 180, 399.

29 Philip J. Finkelpearl, John Marston of the Middle Temple. An Elizabethan Dramatist in His Social Setting (Cambridge, Mass., 1969), 42.

30 Rossaline in Marston's Antonio and Mellida does not fancy an impotent husband; she wants a "full cheek'd gallant with a bouncing thigh". See the play edited G.K. Hunter in Regents Renaissance Drama Series (London, 1965), I.1.110. Juliet in Shakespeare's tragedy has a "quivering thigh" (II.1.19) and Posthumus in Cymbeline a "martial thigh" (IV.2.310).

31 For other contemporary instances of "eye" meaning "pudendum muliebre" see Eric Partridge, Shakespeare's Bawdy (London, 1968), 102; Herbert A. Ellis, Shakespeare's Lusty Punning in Love's Labour's Lost (The Hague, 1973), 48; James T. Henke, Renaissance Dramatic Bawdy (Exclusive of Shakespeare): An Annotated Glossary and Critical Essays, Salzburg Studies in English Literature, Jacobean Drama Studies, 40 (Salzburg, 1974), ii, 147. One of the bawdy jests told by Sir Nicholas Le Strange leaves no doubt about "eye" as a genital metaphor. See the "Merry Passages and Jeasts': A Manuscript Jestbook of Sir Nicholas Le Strange(1603-1633), ed. H.F. Lippincott, Salzburg Studies in English Literature, 29 (Salzburg, 1974), 155.

32 For the two meanings of "minikin" see $O E D$.

33 The Poems of John Marston, ed. Arnold Davenport (Liverpool Univ. Press, 1961), 67.

34 John Marston, The Malcontent, ed. M.L. Wine in Regents Renaissance Drama Series (London, 1965), lines 19-20. The Induction was written by John Webster.

35 Everard Guilpin, Skialetheia or A Shadowe of Truth, in Certaine Epigrams and Satyres, ed. D. Allen Carroll (Chapel Hill, 1974), 51.

36 The Three Pamassus Plays (1598-1601), ed James Blair Leishman (London, 1949), p. 297, lines 1187 ff. 


\section{0 / Renaissance and Reformation}

37 Ben Jonson, ed. C.H. Herford \& P. Simpson, iii (Oxford, 1927; rpt. 1966), p. 526, III.9.78 ff. Gallants who affected smoking tobacco and playing the bass viol became a stage convention about 1599. Gregory Gudgeon who pursues "city lechery" keeps "a viol de gambo and good tobacco". See Thomas Middleton, The Family of Love (1602) in The Dramatic Works of Thomas Middleton, ed. A.H. Bullen, iii (Boston, 1885), II.3.91-2.

38 For this conceit see Marcel Françon, "Un motif de la poésie amoureuse au 16e siècle”, PMLA, 56 (1941), 307-36; Gordon I. Williams, "The Metamorphosis of an Elizabethan Conceit", Trivium, 4 (1969), 96-107.

39 John Hollander in The Untuning of the Sky. Ideas of Music in English Poetry 1500-1700 (Princeton, 1961), p. 133, quotes, from the 1599 version of Michael Drayton's Idea, the ninth sonnet ending with the couplet "Thus like a Lute or Violl did I lye,/ Whilst the proud slaue daunc'd galliards in her eye."

40 The Poems of John Donne, ed. E.K. Chambers (London, 1896), ii, 269.

41 John Aubrey, Brief Lives, ed. A. Clark (Oxford, 1898), ii, 48.

42 Benjamin Rudyerd, Le Prince d'Amour or The Prince of Love (London, 1660), 45. In John Johnson's The Academy of Love (1641), Cupid holds the same idea about sexually exhausted men. The Academy, he explains, has "very few men but they are experienced in the Vi-hole [viola], and when they have almost spent their substance, then they begin to practise the Base: the men practise much of the Virgin-holes" [virginals], (pp. 88-9).

43 Thomas Vicary, The Anatomie of the Bodie of Man (1577), ed. F.J. Furnivall \& P. Furnivall, Early Eng. Text Society, Extra Series, 53 (London, 1888). The relevant passage reads (p. 78): "the feelde of generation called the Matrix, or the mother, is knowen in the anatomie, whose place is properly betwixt the Bladder and Longaon in the woman, in which place is sowen, by the tillage of man, a conuenable matter of kindly heate; for kindley heate is cause efficeens bothe of dooing and working, and spirite that geueth vertue to the body ... the which seede of generation commeth from al the partes of the body."

44 E.A.M. Colman, The Dramatic Use of Bawdy in Shakespeare (London, 1974), 108, 203; Ellis, 64-5, 107.

45 Henke, ii, 83, under "Arrow".

46 The Elizabethan spelling of "vial" was frequently identical with "viol" and vice versa. Henke has an entry under "Viol".

47 See Bullen's edition, iii (1885), p. 147, I.2.76-7.

48 Ed. G.J. Watson in The New Mermaid Series (London, 1968), p. 10, I.1.131 ff.

49 This passage recalls Hamlet's exposure of Rosencrantz and Guildenstern as two sexual deviants. See Charles Clay Doyle, "Blow Below the Belt: Hamlet's Crude Insult", Maledicta, 2 (1978), 1977-81. It is also reminiscent of Pieter Brueghel's copperplate engraving "The Witch of Malleghem" (before 1569) which satirizes the ritual of castration. Behind the witch performing the criminal ritual there is another hag holding a bass viol upside-down in her left hand as if comforting the emasculated victim with the prospect of gratifying, in future, his sexual instincts by playing on the viol da gamba.

50 It should be noted that "to play on" an instrument can also mean "to fondle sexually." See Henke under "Cittern", p. 108. 